\title{
Solanapyrone Analogues from a Hawaiian Fungicolous Fungus
}

\author{
Lori E. Schmidt ${ }^{\dagger}$, James B. Gloer ${ }^{\dagger},{ }^{\star}$, and Donald T. Wicklow ${ }^{\ddagger}$ \\ $\dagger$ Department of Chemistry, University of Iowa, Iowa City, IA, 52242 \\ $\$$ Mycotoxin Research Unit, Agricultural Research Service, USDA National Center for Agricultural \\ Utilization Research, USDA, Peoria, IL, 61604
}

\begin{abstract}
Four new solanapyrone analogues (solanapyrones J-M; 1-4) have been isolated from an unidentified fungicolous fungus collected in Hawaii. The structures and relative configurations of these compounds were determined by analysis of 1D NMR, 2D NMR, and MS data. Solanapyrone J (1) showed antifungal activity against Aspergillus flavus and Fusarium verticillioides, while both $\mathbf{1}$ and $\mathbf{2}$ showed activity against Staphylococcus aureus and Candida albicans.
\end{abstract}

Our studies of fungicolous and mycoparasitic fungi have resulted in the discovery of many new bioactive natural products. ${ }^{1,2}$ Recently, a collection of such fungi obtained from the island of Hawaii have begun to afford similar results. ${ }^{3,4}$ In the course of this work, chemical investigation of an unidentified Hawaiian fungicolous isolate (MYC- 1710) led to the isolation of four new antimicrobial compounds (1-4) that were identified as new analogues of the solanapyrones. ${ }^{5-10}$ Solanapyrones have been previously reported from the fungi Alternaria solani ${ }^{5-7}$ and Ascochyta rabiei, ${ }^{8}$ as well as an unidentified filamentous fungus obtained from the surface of a marine alga. ${ }^{9}$ Members of this group have been found to show phytotoxicity $7-9,11$ and inhibition of DNA polymerases $\beta$ and $\lambda .{ }^{12}$ Details of the isolation and structure elucidation of compounds 1-4 are presented here.

\section{Results and Discussion}

MYC-1710 was obtained from the surface of a black stroma of an unidentified pyrenomycete on a dead hardwood branch collected in a Hawaiian forest. The fungus was cultured by solidsubstrate fermentation on rice, and the EtOAc extract of the resulting fermentation mixture showed antifungal activity against Aspergillus flavus and Fusarium verticillioides, and was therefore subjected to chemical investigation, leading to the isolation of compounds 1-4.

The most abundant component (1) was found to have the molecular formula $\mathrm{C}_{20} \mathrm{H}_{26} \mathrm{O}_{4}$ (eight unsaturations) on the basis of MS and NMR data. In the ${ }^{1} \mathrm{H}$ NMR spectrum (Table 1), signals were observed for an aldehyde group, an isolated olefinic or aromatic proton, and two vicinally coupled olefinic protons. One methoxy resonance, three other methyl signals (two doublets and one singlet), and multiple $\mathrm{sp}^{3}$ methine and methylene signals were also present. In addition to the aldehyde signal, the ${ }^{13} \mathrm{C}$ NMR spectrum (Table 2) revealed three oxygenated olefin or carbonyl carbon signals, and two upfield-shifted $\mathrm{sp}^{2}$ carbon signals suggestive of a $\beta$ oxygenated $\alpha$-pyrone unit, ${ }^{5-10}$ along with two olefinic signals corresponding to the 1,2 disubstituted double bond, the methoxy group, and 11 other aliphatic carbons. These units account for six degrees of unsaturation, requiring two additional rings to be present.

\footnotetext{
*To whom correspondence should be addressed. Tel: 319-335-1361. Fax 319-335-1270. E-mail: james-gloer@uiowa.edu.

$\dagger$ University of Iowa

\#USDA National Center for Agricultural Utilization Research
} 
The presence and substitution pattern of the $\alpha$-pyrone unit was confirmed by HMBC data and by comparison of shift data with those of solanapyrone A. ${ }^{7}$ HMBC correlations from the methoxy signal to C-13, and from the isolated olefinic proton H-12 to C-11, C-13, and C-14, placed the upfield-shifted $\mathrm{C}-12$ between the downfield-shifted $\mathrm{C}-11$ and $\mathrm{C}-13$. Correlations from the aldehyde proton $\mathrm{H}-17$ to $\mathrm{C}-13, \mathrm{C}-14$, and $\mathrm{C}-15$ allowed location of the aldehyde group adjacent to the pyrone carbonyl (at C-14). Correlations from $\mathrm{H}-12$ to $\mathrm{C}-1$ and from $\mathrm{H}_{3}-19$ to $\mathrm{C}-11$ enabled connection of the pyrone ring of $\mathbf{1}$ to the remainder of the molecule at $\mathrm{C}-11$.

The remaining units in the molecule were linked to form a modified decalin system by analysis of HMBC and ${ }^{1} \mathrm{H}$ NMR coupling data. The three methyl signals for $\mathrm{H}_{3}-16, \mathrm{H}_{3}-18$, and $\mathrm{H}_{3}-19$ all clearly showed the expected two- and three-bond HMBC correlations enabling construction of a sizable portion of the molecule that accounted for all of structure 1 except for the C-5C-6-C-7 unit. Coupling of H-5 to both olefinic protons $\mathrm{H}-3$ and H-4, as well as to H-10, enabled connection of $\mathrm{C}-5$ to $\mathrm{C}-4$ and $\mathrm{C}-10$ to complete a cyclohexene ring. The two remaining methylene units (C-6 and C-7) must bridge C-5 and C-8 to complete the structure of 1 . These conclusions were supported by additional HMBC data. Structure 1 differs from that of solanapyrone A in the presence of two additional methyl groups attached at positions $\mathrm{C}-1$ and $\mathrm{C}-9$. The name solanapyrone $\mathbf{J}$ is proposed for compound $\mathbf{1}$, and the numbering system shown is consistent with that of previously reported solanapyrones. $5-10$

Analysis of NOESY data (Figure 1) and ${ }^{1} \mathrm{H}$ NMR $J$-values enabled assignment of the relative configuration of 1 . A correlation between $\mathrm{H}-2$ and $\mathrm{H}-10$ required these two protons to be $c$ is to one another and pseudo-diaxial with respect to the cyclohexene ring. Similarly, a correlation between $\mathrm{H}-5$ and $\mathrm{H}_{3}-18$ place these protons on the other face of the fused ring system and 1,3diaxial (or pseudo-diaxial) with respect to the cyclohexane ring. The resulting cis ring fusion was consistent with observation of a NOESY correlation between H-5 and H-10. Further correlations of $\mathrm{H}_{3}-19$ with $\mathrm{H}_{3}-16$ and of $\mathrm{H}-12$ with $\mathrm{H}-2$ led to assignment of the remaining configuration at C-1 as shown. Other NOESY correlations were also consistent with this overall stereochemical assignment. Most of the vicinal coupling values for the cyclohexane portion of the molecule could not be discerned due to broadness and/or overlap of the signals, although the $J_{\mathrm{H} 5-\mathrm{H} 10}$ value was observed $(7.2 \mathrm{~Hz})$. This value is a bit larger than expected for a standard cis ring fusion relationship, but was clearly smaller than that of the trans value observed for $4(9.9 \mathrm{~Hz}$; see below). The conformation adopted by $\mathbf{1}$ (and therefore the $\mathrm{H} 5-\mathrm{H} 10$ vicinal angle) would likely be influenced to some degree by the nearby substituents at C-1 and C-9, as well as the presence of the olefin, and would have more flexibility than a transfused analog (e.g., 4). Molecular modeling (ChemDraw Pro 9.0) suggests that the lowest energy conformation of the cyclohexane ring in $\mathbf{1}$ may be a twisted chair, resulting in a smaller H5-H10 vicinal angle (and a somewhat larger $J$-value) than would be expected for a simple decalin system. On the basis of the NOESY data, solanapyrone $\mathbf{J}(\mathbf{1})$ was assigned the relative configuration shown, which matched that reported for solanapyrone A at relevant stereocenters C-2, C-5, and $\mathrm{C}-10 .^{7}$ The orientation of the pyrone substituent also matches that of the other known solanapyrones.

Compound 2 was assigned the molecular formula $\mathrm{C}_{21} \mathrm{H}_{29} \mathrm{O}_{4} \mathrm{~N}$ (eight unsaturations) on the basis of HRESIMS and NMR data. However, the ${ }^{13} \mathrm{C}$ and ${ }^{1} \mathrm{H}$ NMR spectra (Tables 2 and 3, respectively) each showed the presence of two distinct sets of signals. Since the two constituents could not be separated, analysis was carried out on the mixture, with a focus on the major component. The ${ }^{1} \mathrm{H}$ and ${ }^{13} \mathrm{C}$ NMR data for the major component lacked the aldehyde and methoxy signals observed in the data for $\mathbf{1}$, but included additional resonances for a ketone group, an NH proton, two more methylene units, and an $\mathrm{OH}$ group. The latter signals were suggestive of an ethanolamine unit. All of the ${ }^{1} \mathrm{H}$ NMR $\delta$ - and $J$-values for the modified decalin system are very similar to those of $\mathbf{1}$, suggesting that this portion of the molecule is identical to the corresponding portion of $\mathbf{1}$ (including relative configuration), and the connectivity of 
this subunit was independently confirmed by analysis of HMBC data. Other key correlations were observed from $\mathrm{H}-12$ to $\mathrm{C}-1, \mathrm{C}-11$, and non-protonated olefinic carbon $\mathrm{C}-14$, and from olefin proton $\mathrm{H}-17$ to $\mathrm{C}-13, \mathrm{C}-14$, and C-20 (of the ethanolamine unit), enabling attachment of the $\mathrm{C} 20-\mathrm{C} 21$ ethanolamine unit at $\mathrm{C}-17$ to form a cross-conjugated enamine. This structure rationalized the appearance of two sets of signals for the upper portion of the molecule due to the two possible intramolecularly hydrogen-bonded forms it can adopt. These two forms are geometric isomers of each other, but are inseparable and presumably in equilibrium via a process involving keto-enol tautomerism. The large coupling constants observed for the H-17 signals for each isomer result from hydrogen- bonding of the $\mathrm{NH}$ proton to the carbonyl oxygen atoms at positions 13 or 15 , which requires a near- $180^{\circ}$ vicinal angle for the $\mathrm{NH}$ and $\mathrm{H}-17$ protons in each of the two possible forms. Interestingly, an ethanolamine unit is also present in solanapyrone $\mathrm{C},{ }^{8}$ but is attached at $\mathrm{C}-13$, rather than $\mathrm{C}-17$ and therefore does not show this property. . However, several synthetic systems similar to the upper portion of $\mathbf{2}$ have been studied by Uray et al. ${ }^{13}$ As in the case of 2 , these researchers found that two sets of signals are observed for such enamines, and in each set, a large $J_{\mathrm{CH}-\mathrm{NH}^{-}}$-value is evident. In all of the compounds surveyed, the $\mathrm{CH}$ signal has a slightly more downfield shift in the isomer with hydrogen bonding of the $\mathrm{NH}$ to the ester oxygen. In addition, as in the data for $\mathbf{2}$, this signal is consistently less intense and has a slightly larger $J$-value than its counterpart. Thus, the signals for the two forms of $\mathbf{2}$ were assigned as shown by analogy to these synthetic model compounds. The name solanapyrone $\mathrm{K}$ is proposed for compound $\mathbf{2}$.

The molecular formula for compound 3 was determined to be $\mathrm{C}_{19} \mathrm{H}_{25} \mathrm{O}_{3} \mathrm{~N}$ (eight unsaturations) on the basis of HRESIMS and NMR data. Analysis of NMR data revealed that $\mathbf{3}$ is related to $\mathbf{1}$ and $\mathbf{2}$, but lacks the two methylene signals for the ethanolamine unit in $\mathbf{2}$, and instead shows a second NH signal in the ${ }^{1} \mathrm{H}$ NMR spectrum. All of the other ${ }^{1} \mathrm{H}$ NMR $\delta$ - and $J$-values are nearly identical to those of $\mathbf{2}$, suggesting that $\mathbf{3}$ lacks the $\mathrm{CH}_{2} \mathrm{CH}_{2} \mathrm{OH}$ unit, but is otherwise identical to 2 and is proposed to have the same relative configuration. The name solanapyrone $\mathrm{L}$ is proposed for compound $\mathbf{3}$.

Compound 4 was determined to have the molecular formula $\mathrm{C}_{20} \mathrm{H}_{28} \mathrm{O}_{4}$ (seven unsaturations) on the basis of HRESIMS and NMR data. The ${ }^{1} \mathrm{H}$ NMR spectrum of $\mathbf{4}$ (Table 1) is very similar to that of $\mathbf{1}$ except that the aldehyde signal is replaced by a twoproton singlet at $\delta 4.54$

characteristic of an oxymethylene unit. HMBC correlations confirmed that the connectivity of $\mathbf{4}$ matches that of $\mathbf{1}$ except for replacement of the aldehyde with a $\mathrm{CH}_{2} \mathrm{OH}$ unit. In addition, however, the chemical shifts and $J$-values for several of the signals for the decalin-type portion of the molecule (Table 1) were significantly different from the corresponding signals in the ${ }^{1} \mathrm{H}$ NMR spectrum of $\mathbf{1}$, suggesting that $\mathbf{4}$ possesses a different relative configuration. Analysis of NOESY data (Figure 1) and $J$-values confirmed this suggestion and established the relative configuration of 4 . A correlation between $\mathrm{H}_{3}-16$ and $\mathrm{H}-10$ required both $\mathrm{CH}_{3}-16$ and $\mathrm{H}-10$ to be in pseudoaxial orientations and cis to one another, in contrast to the situation in 1. Additional correlations of $\mathrm{H}-10$ with $\mathrm{H}-6_{\mathrm{ax}}$ and $\mathrm{H}-\mathrm{g}_{\mathrm{ax}}$ supported assignment of an axial orientation for $\mathrm{H}-10$, as did large trans-diaxial $J_{\mathrm{H} 5-\mathrm{H} 10}$ and $J_{\mathrm{H} 9-\mathrm{H} 10}$ values. The large vicinal couplings ( $9.9 \mathrm{~Hz}$ each) observed between $\mathrm{H}-5$ and $\mathrm{H}-10$ and between $\mathrm{H}-5$ and $\mathrm{H}-6_{\mathrm{ax}}$ also indicated an axial orientation for $\mathrm{H}-5$, and established the presence of a trans ring fusion. Other NOESY correlations were consistent with these assignments. These data permitted assignment of the relative configuration of $\mathbf{4}$ as shown, matching those reported for solanapyrones $\mathrm{D}$ and $\mathrm{E}$ at positions C-2, C-5, and C-10, ${ }^{7}$ and differing from 1 at the C-2 and C-5 positions. Chemical shift differences between $\mathbf{1}$ and $\mathbf{4}$ at affected positions are consistent with similar variations observed among previously reported solanapyrones exhibiting similar stereochemical differences. The name solanapyrone $\mathrm{M}$ is proposed for $\mathbf{4}$.

The occurrence of solanapyrones having these two types of relative configurations has been proposed to be due to formation of the modified decalin system via an intramolecular Diels- 
Alder reaction of a polyketide-derived pro-solanapyrone species to give exo (e.g., 1-3) or endo (e.g., 4) products. ${ }^{14,15}$ The absolute configurations of 1-4 were not independently assigned, but are presumed to match those of the previously known solanapyrones. Like all other solanapyrones for which values have been previously reported, 1-4 all display negative optical rotations, although this alone does not enable an unambiguous stereochemical assignment.

Solanapyrone J (1) showed antifungal activity against Aspergillus flavus (NRRL 6541) and Fusarium verticillioides (NRRL 25457), affording clear zones of $\mathrm{ca} .30 \mathrm{~mm}$ diameter in disk assays against both organisms at $200 \mu \mathrm{g} /$ disk that persisted for four days. Upon further evaluation, ${ }^{16}$ compound 1 displayed MIC values of approximately 20 and $24 \mu \mathrm{g} / \mathrm{mL}$ against A. flavus and $F$. verticillioides, respectively, and $\mathrm{IC}_{50}$ values of approximately 8.6 and $15 \mu \mathrm{g} /$ $\mathrm{mL}$. Nystatin, an antifungal standard, afforded MIC values of approximately $10 \mu \mathrm{g} / \mathrm{mL}$ in both assays and $\mathrm{IC}_{50}$ values of 5 and $3 \mu \mathrm{g} / \mathrm{mL}$, respectively, using the same protocols. Compounds 2-4 were much less abundant than $\mathbf{1}$, and were not tested in these assays due to sample limitations. Compounds 1 and $\mathbf{2}$ showed antibacterial activity in standard disk assays 17,18 against Staphylococcus aureus (ATCC 25923), with 1 affording a clear zone of inhibition of $17 \mathrm{~mm}$ and a zone of reduced growth of $21 \mathrm{~mm}$ and 2 affording a zone of inhibition of $9 \mathrm{~mm}$ at $50 \mu \mathrm{g} / \mathrm{disk}$ after four days (a gentamicin sulfate standard gave a $25-\mathrm{mm}$ clear zone in this assay at $25 \mu \mathrm{g} / \mathrm{disk}$ ). Compounds $\mathbf{1}$ and $\mathbf{2}$ were also active against Candida albicans (ATCC 14053) affording zones of inhibition of 19 and $13 \mathrm{~mm}$, respectively, under the same conditions (a filipin standard gave a 23-mm clear zone in the assay at $50 \mu \mathrm{g} / \mathrm{disk}$ ). Compounds 3 and $\mathbf{4}$ showed no activity in either of these assays, and none of the compounds showed activity against Escherichia coli (ATCC 25922) when tested at the same level.

\section{Experimental Section}

\section{General Experimental Procedures}

${ }^{1} \mathrm{H}$ and ${ }^{13} \mathrm{C}$ NMR spectra were measured on Bruker AVANCE-300, DRX-400, and

AVANCE-600 spectrometers. Chemical shift values were referenced to residual solvent signals for $\mathrm{CDCl}_{3}\left(\delta_{\mathrm{H}} / \delta_{\mathrm{C}}, 7.24 / 77.0\right)$. HMQC and $\mathrm{HMBC}$ data were recorded on a Bruker AVANCE-600. HPLC was carried out using a Beckman System Gold HPLC instrument with a model 168 variable wavelength UV detector. HRESIMS data were recorded on a Thermo LTQ fourier transform instrument (Washington University Mass Spectrometry Resource). Optical rotations were measured with a Rudolph automatic polarimeter, model AP III. Standards of nystatin, gentamicin sulfate, and filipin were purchased from Sigma Chemical Co.

\section{Isolation, Cultivation, and Fermentation of Fungal Material}

An isolate (MYC-1710) was obtained from the surface of a black stroma of an unidentified pyrenomycete on a dead hardwood branch collected in a montane dry forest (Ohi'a) Koloko St., Kailua-Kona, Hawaii Co., HI, on November 3, 2002. The fungus was grown on $100 \mathrm{~g}$ of autoclaved rice for 30 days at $25^{\circ} \mathrm{C}$. The EtOAc extract $(448 \mathrm{mg}$ ) of the resulting fermentation mixture showed antifungal activity against $A$. flavus and $F$. verticillioides. The isolate was not taxonomically identified, as scale-up attempts revealed that the cultures and backups thereof were no longer viable, despite storage of cultures at both $-20^{\circ} \mathrm{C}$ and $5{ }^{\circ} \mathrm{C}$. Unfortunately, efforts to extract DNA from the stock culture material failed to recover an intact ITS-lsu DNA fragment that might have enabled identification or partial classification of the fungus. Efforts to re-isolate the fungus from a sample of the original substrate stromata, and from other stromata collected at the same location, all of which were continuously stored at $5{ }^{\circ} \mathrm{C}$ since collection, have thus far been unsuccessful. 


\section{Extraction and Isolation}

The extract was partitioned between $\mathrm{MeCN}$ and hexanes ( $3 \mathrm{~mL}$ of each). The resulting $\mathrm{MeCN}$ fraction $\left(360 \mathrm{mg}\right.$ ) was then chromatographed on a silica gel column using a hexanes/ $\mathrm{CH}_{2} \mathrm{Cl}_{2} /$ $\mathrm{MeOH}$ step gradient (hexanes, $\mathrm{CH}_{2} \mathrm{Cl}_{2}, \mathrm{CH}_{2} \mathrm{Cl}_{2} / \mathrm{MeOH}$ 19:1, 9:1, 17:3, 4:1, 7:3, 1:1, and 1:4) to give eleven fractions. Fraction $3(84 \mathrm{mg})$, eluted with $\mathrm{CH}_{2} \mathrm{Cl}_{2}$, was further separated by reversed-phase HPLC $\left(50 \% \mathrm{MeCN} / \mathrm{H}_{2} \mathrm{O}\right.$ isocratic for five min, 50-100\% over $35 \mathrm{~min}$, and $100 \%$ for $10 \mathrm{~min})$ on a HS Hyperprep BDS $8-\mu \mathrm{m} \mathrm{C}_{18}$ column $(4.6 \times 250 \mathrm{~mm})$ at a flow rate of $2 \mathrm{~mL} / \mathrm{min}$ with UV detection at $215 \mathrm{~nm}$ to afford solanapyrone $\mathbf{J}\left(\mathbf{1} ; 30 \mathrm{mg}, \mathrm{t}_{\mathrm{R}} 28.8 \mathrm{~min}\right)$. Fraction 5 (149 mg), eluted with 19:1 $\mathrm{CH}_{2} \mathrm{Cl}_{2} / \mathrm{MeOH}$, was separated by reversed-phase HPLC (same column as above; $30 \% \mathrm{MeCN} / \mathrm{H}_{2} \mathrm{O}$ isocratic for five min, 30-60\% over $25 \mathrm{~min}, 60 \%$ isocratic for $20 \mathrm{~min}$, and $60-100 \%$ over $10 \mathrm{~min}$ ) to afford an additional sample of solanapyrone $\mathrm{J}\left(\mathbf{1} ; 8 \mathrm{mg}, \mathrm{t}_{\mathrm{R}} 43.6 \mathrm{~min}\right)$, as well as two other subfractions which were further purified. Subfraction $5(3 \mathrm{mg})$ was purified by reversed-phase HPLC $\left(65-72 \% \mathrm{MeCN} / \mathrm{H}_{2} \mathrm{O}\right.$ over $35 \mathrm{~min}$ and $72-100 \%$ over $1 \mathrm{~min}$ ) on the same column with UV detection at $215 \mathrm{~nm}$ to afford solanapyrone $\mathrm{K}\left(2 ; 2 \mathrm{mg}, \mathrm{t}_{\mathrm{R}} 25.0 \mathrm{~min}\right)$ and solanapyrone $\mathrm{L}\left(\mathbf{4} ; 1 \mathrm{mg}, \mathrm{t}_{\mathrm{R}} 26.5 \mathrm{~min}\right)$. Subfraction $7(2 \mathrm{mg})$ was further purified by reversed-phase HPLC $\left(55 \% \mathrm{MeCN} / \mathrm{H}_{2} \mathrm{O}\right.$ isocratic for $30 \mathrm{~min}$ and $55-100 \%$ over $1 \mathrm{~min}$ ) on the same column with UV detection at $215 \mathrm{~nm}$ to afford solanapyrone $\mathrm{M}\left(\mathbf{3} ; 1 \mathrm{mg}, \mathrm{t}_{\mathrm{R}} 26.0 \mathrm{~min}\right)$.

\section{Solanapyrone $\mathrm{J}(1)$}

yellow glass; $[\alpha]^{25} \mathrm{D}^{-114}(\mathrm{c} 1.3, \mathrm{MeOH}) ;{ }^{1} \mathrm{H}$ and ${ }^{13} \mathrm{C}$ NMR data, see Tables 1 and 2 ; HMBC data: $\mathrm{H}-2 \rightarrow \mathrm{C}-1,3,4,16$; H-3 $\rightarrow \mathrm{C}-1,2,5,16$; H-4 $\rightarrow$ C-2, 5, 6, 10; H-5 $\rightarrow$ C-1, 3, 4, 6, 7, $10 ; \mathrm{H}_{2}-6 \rightarrow \mathrm{C}-4,5,7,8,10 ; \mathrm{H}_{2}-7 \rightarrow \mathrm{C}-5,6,8,9 ; \mathrm{H}_{2}-8 \rightarrow \mathrm{C}-6,7,9,10,18 ; \mathrm{H}-9 \rightarrow \mathrm{C}-1,7,8$, $18 ; \mathrm{H}-10 \rightarrow \mathrm{C}-1,9,18,19 ; \mathrm{H}-12 \rightarrow \mathrm{C}-1,11,13,14 ; \mathrm{H}_{3}-16 \rightarrow \mathrm{C}-1,2,3 ; \mathrm{H}-17 \rightarrow \mathrm{C}-13,14$, $15 ; \mathrm{H}_{3}-18 \rightarrow \mathrm{C}-8,9,10 ; \mathrm{H}_{3}-19 \rightarrow \mathrm{C}-1,2,10,11 ; \mathrm{MeO} \rightarrow \mathrm{C}-13$; HRESIMS obsd $m / z 331.1902$, calcd for $\mathrm{C}_{20} \mathrm{H}_{27} \mathrm{O}_{4}(\mathrm{M}+\mathrm{H})^{+}, 331.1910$.

\section{Solanapyrone K (2)}

colorless oil; $[\alpha]^{25} \mathrm{D}-45(c 0.12, \mathrm{MeOH}) ;{ }^{1} \mathrm{H}$ and ${ }^{13} \mathrm{C}$ NMR data, see Tables 2 and 3; HMBC data: H-2 $\rightarrow$ C-10, 16; H-3 $\rightarrow$ C-1, 2, 5, 16; H-4 $\rightarrow$ C-5; H-5 $\rightarrow$ C- $1 ; \mathrm{H}_{2}-6 \rightarrow$ C-5; $\mathrm{H}_{2}-7 \rightarrow$ $\mathrm{C}-5,9 ; \mathrm{H}_{2}-8 \rightarrow \mathrm{C}-7 ; \mathrm{H}-9 \rightarrow \mathrm{C}-5,18 ; \mathrm{H}-10 \rightarrow \mathrm{C}-1,5 ; \mathrm{H}-12 \rightarrow \mathrm{C}-1,11,14 ; \mathrm{H}_{3}-16 \rightarrow \mathrm{C}-1,2$, $3 ; \mathrm{H}-17 \rightarrow \mathrm{C}-13,14,15,20 ; \mathrm{H}_{3}-18 \rightarrow \mathrm{C}-8,9,10 ; \mathrm{H}_{3}-19 \rightarrow \mathrm{C}-1,2,10,11 ; \mathrm{H}_{2}-21 \rightarrow \mathrm{C}-20$; HRESIMS obsd $\mathrm{m} / \mathrm{z} 360.2166$, calcd for $\mathrm{C}_{21} \mathrm{H}_{30} \mathrm{O}_{4} \mathrm{~N}(\mathrm{M}+\mathrm{H})^{+}, 360.2176$.

\section{Solanapyrone L (3)}

colorless oil; $[\alpha]^{25} \mathrm{D}-53(c 0.04, \mathrm{MeOH}) ;{ }^{13} \mathrm{C}$ NMR data, see Table $2 ;{ }^{1} \mathrm{H}$ NMR $(400 \mathrm{MHz}$, $\mathrm{CDCl}_{3}$ ) $\delta 11.2$ (br s, $\mathrm{NH}_{\text {major }}$ ), 9.57 (br s, $\mathrm{NH}_{\text {minor }}$ ), 8.46 (dd, 16, $8.7 \mathrm{~Hz}, \mathrm{H}-17$ minor) $), 8.33$ (dd, $15 \mathrm{~Hz}, 8.9 \mathrm{~Hz}, \mathrm{H}-17_{\text {major }}$ ), 6.70 (br s, NH), 5.91 (s, H-12 minor), 5.86 (s, H-12 major $), 5.58$ (dt, 10, 3.5 Hz, H-4), 5.30 (dt, 10, 2.0 Hz, H-3), 2.89 (br m, H-2), 2.40 (br m, H-5), 2.21 (br d, 7.3 Hz, H-10), 1.73 (m, H- eq $_{\text {eq }}$ ), 1.52 (m, H-9), 1.50 (m, 2H, H-7 eq $\mathrm{H}-8_{\mathrm{ax}}$ ), 1.48 (m, H-7 $\mathrm{ax}$ ), 1.34 (br d, $12 \mathrm{~Hz}, \mathrm{H}-8_{\mathrm{eq}}$ ), 1.23 (m, H-6 $6_{\mathrm{ax}}$ ), 1.04 (s, $\left.\mathrm{H}_{3}-19\right), 0.99$ (d, $7.3 \mathrm{~Hz}, \mathrm{H}_{3}-18$ ), 0.77 (d, 7.4 Hz, $\left.\mathrm{H}_{3}-16\right)$. HRESIMS obsd $\mathrm{m} / z$ 316.1904, calcd for $\mathrm{C}_{19} \mathrm{H}_{26} \mathrm{O}_{3} \mathrm{~N}(\mathrm{M}+\mathrm{H})^{+}, 316.1914$.

\section{Solanapyrone M (4)}

colorless oil; $[\alpha]^{25} \mathrm{D}-84$ ( $\left.c 0.025, \mathrm{MeOH}\right) ;{ }^{1} \mathrm{H}$ and ${ }^{13} \mathrm{C}$ NMR data, see Tables 1 and 2; HMBC data: $\mathrm{H}-2 \rightarrow \mathrm{C}-1,3,16 ; \mathrm{H}-3 \rightarrow \mathrm{C}-2,4$; H-4 $\rightarrow$ C-2, 3, 5, 6; H $\mathrm{H}_{2}-6 \rightarrow \mathrm{C}-5 ; \mathrm{H}_{2}-7 \rightarrow \mathrm{C}-6$; H-9 $\rightarrow$ $\mathrm{C}-18 ; \mathrm{H}-10 \rightarrow \mathrm{C}-1,5,6,8,9,19 ; \mathrm{H}-12 \rightarrow \mathrm{C}-1,11,13,14 ; \mathrm{H}_{3}-16 \rightarrow \mathrm{C}-2,3 ; \mathrm{H}-17 \rightarrow \mathrm{C}-13$, 14,$15 ; \mathrm{H}_{3}-18 \rightarrow \mathrm{C}-8,9,10 ; \mathrm{H}_{3}-19 \rightarrow \mathrm{C}-1,2,10,11 ; \mathrm{MeO} \rightarrow \mathrm{C}-13$; HRESIMS obsd $\mathrm{m} / \mathrm{z}$ 333.2060, calcd for $\mathrm{C}_{20} \mathrm{H}_{29} \mathrm{O}_{4}(\mathrm{M}+\mathrm{H})^{+}, 333.2067$. 


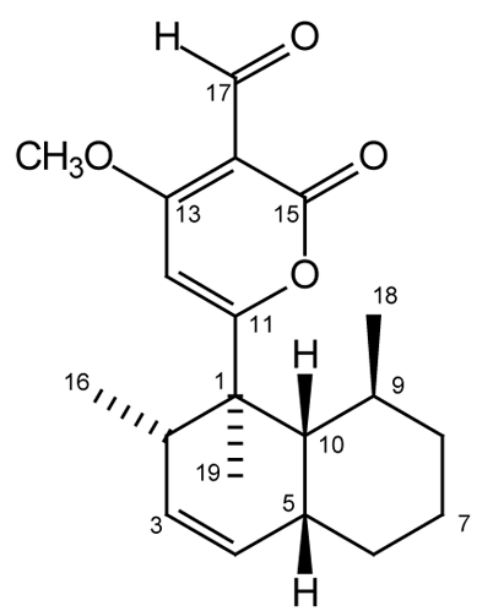

1

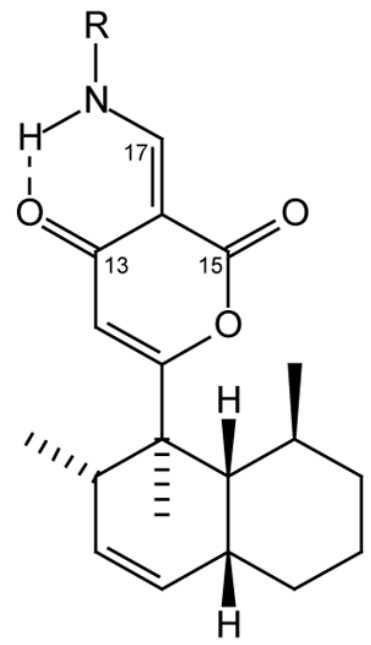

(major)<smiles>C#C[C@]12C#C[C@@H](C)C=CC1=C(c1cc(OC)c(CO)c(=O)o1)[C@@H]2C</smiles>

4<smiles></smiles>

(minor)

$$
\begin{aligned}
& 2 \mathrm{R}={ }^{20} \mathrm{CH}_{2}{ }_{2}^{21} \mathrm{CH}_{2} \mathrm{OH} \\
& 3 \mathrm{R}=\mathrm{H}
\end{aligned}
$$

\section{Supplementary Material}

Refer to Web version on PubMed Central for supplementary material.

\section{Acknowledgements}

This research was supported by grants from the National Science Foundation (\# CHE-0315591) and the National Institutes of Health (GM 60600). 12 Assistance from the staff of the University of Iowa NMR and Mass Spectrometry Facilities is gratefully acknowledged. High resolution MS data were provided by the Washington University Mass Spectrometry Facility, an NIH Research Resource (grant \# P41RR0954). We are also grateful to Professor Don Hemmes of the University of Hawaii at Hilo for guiding the collection of fungal sporocarps from Hawaii. 


\section{References and Notes}

1. Mudur SV, Gloer JB, Wicklow DT. J Antibiot 2006;59:500-506. [PubMed: 17080687]

2. Deyrup ST, Swenson DC, Gloer JB, Wicklow DT. J Nat Prod 2006;69:608-611. [PubMed: 16643036]

3. Shim SH, Swenson DC, Gloer JB, Dowd PF, Wicklow DT. Org Lett 2006;8:1225-1228. [PubMed: 16524309]

4. Shim SH, Gloer JB, Wicklow DT. J Nat Prod 2006;69:1601-1605. [PubMed: 17125229]

5. Ichihara A, Tazaki H, Sakamura S. Tetrahedron Lett 1983;24:5373-5376.

6. Ichihara A, Miki I, Sakamura S. Tetrahedron Lett 1985;26:2453-2454.

7. Oikawa H, Yokota T, Sakano C, Suzuki Y, Naya A, Ichihara A. Biosci Biotechnol Biochem 1998;62:2016-2022.

8. Alam SS, Bilton JM, Slawin MZ, Williams DJ, Sheppard RN, Strange RM. Phytochemistry 1989;28:2627-2630.13.

9. Jenkins KM, Toske SG, Jensen PR, Fenical W. Phytochemistry 1998;49:2299-2304.

10. Schlörke, O. Dissertation. University of Göttingen; 2005.

11. Kaur S. Plant Sci 1995;109:23-29.

12. Mizushina Y, Kamisuki S, Kasai N, Shimazaki N, Takemura M, Asahara H, Linn S, Yoshida S, Matsukage A, Koiwai O, Sugawara F, Yoshida H, Sakaguchi K. J Biol Chem 2002;277:630-638. [PubMed: 11677229]

13. Uray G, Wolfbeis OS, Junek H. J Mol Struct 1979;54:77-88.

14. Oikawa H, Suzuki Y, Naya A, Katayama K, Ichihara A. J Am Chem Soc 1994;116:3605-3606.

15. Oikawa H, Katayama K, Suzuki Y, Ichihara A. J Chem Soc, Chem Commun 1995:1321-1322.

16. Jiao P, Swenson DC, Gloer JB, Campbell J, Shearer CA. J Nat Prod 2006;69:1667-1671. [PubMed: 17190439]

17. Bauer AW, Kirby WM, Sherris JC, Turck M. Am J Clin Pathol 1966;45:493-496. [PubMed: 5325707]

18. Wagenaar MM, Clardy J. J Nat Prod 2001;64:1006-1009. [PubMed: 11520215] 

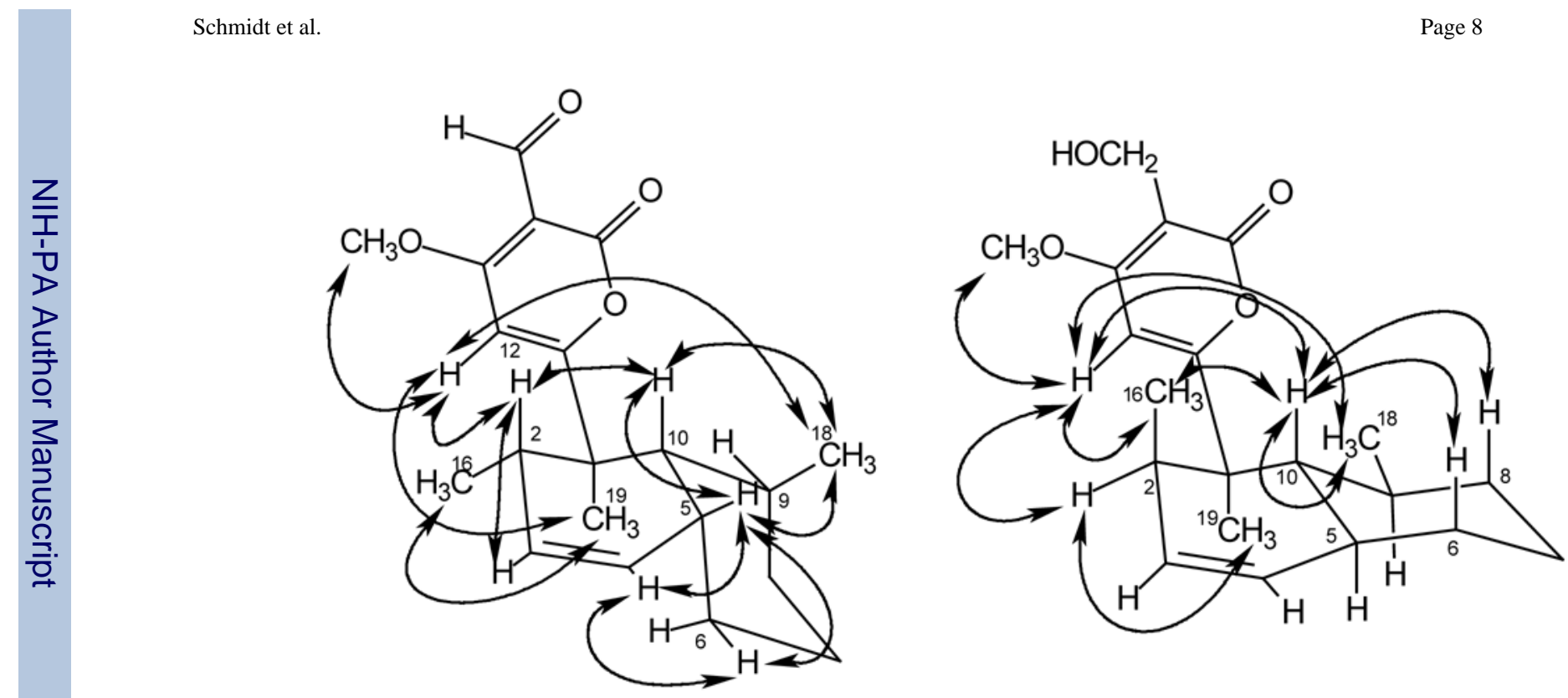

Figure 1.

Selected NOESY correlations for solanapyrone J (1) and solanapyrone M (4) 
Table 1

${ }^{1} \mathrm{H}$ NMR data $\left[\delta_{\mathrm{H}}\left(\right.\right.$ mult, $\left.\left.J_{\mathrm{H}}\right)\right]$ for compounds 1 and 4

\begin{tabular}{|c|c|c|}
\hline position & $1^{a}$ & $4^{b}$ \\
\hline 2 & $2.83($ br m) & $1.87(\mathrm{~m})$ \\
\hline 3 & $5.32(\mathrm{dt}, 9.6,2.0)$ & $5.51(\mathrm{ddd}, 10,4.5,2.5)$ \\
\hline 4 & $5.62(\mathrm{dt} 9.6,3.6)$ & $5.36(\mathrm{br} d, 10)$ \\
\hline 5 & 2.43 (br m) & 1.79 (br m) \\
\hline $6_{e q}$ & $1.60($ br d, 13) & $1.81(\mathrm{~m})$ \\
\hline $6_{\mathrm{ax}}^{\mathrm{q}}$ & $1.23(\mathrm{~m})$ & $1.25(\mathrm{~m})$ \\
\hline $7_{\mathrm{eq}}^{\mathrm{ax}}$ & $1.50(\mathrm{~m})$ & $1.76(\mathrm{~m})$ \\
\hline $7_{\mathrm{ax}}^{\mathrm{eq}}$ & $1.48(\mathrm{~m})$ & $1.41(\mathrm{qt}, 13,3.8)$ \\
\hline 8 & $1.38(\mathrm{br} \mathrm{d}, 12)$ & $1.63($ br d, 13) \\
\hline $8{ }^{e q}$ & $1.50(\mathrm{~m})$ & $1.32(\mathrm{dq}, 4.3,13)$ \\
\hline 9 & $1.51(\mathrm{~m})$ & $1.40(\mathrm{~m})$ \\
\hline 10 & $2.30($ br d, 7.2$)$ & $1.94(\mathrm{t}, 9.9)$ \\
\hline 12 & $6.20(\mathrm{~s})$ & $6.20(\mathrm{~s})$ \\
\hline 16 & $0.76(\mathrm{~d}, 7.2)$ & $0.85(\mathrm{~d}, 6.9)$ \\
\hline 17 & $10.14(\mathrm{~s})$ & $4.54(\mathrm{~s})$ \\
\hline 18 & $0.99(\mathrm{~d}, 7.4)$ & $0.62(\mathrm{~d}, 6.7)$ \\
\hline 19 & $1.17(\mathrm{~s})$ & $1.28(\mathrm{~s})$ \\
\hline $\mathrm{MeO}$ & $4.07(\mathrm{~s})$ & $3.90(\mathrm{~s})$ \\
\hline
\end{tabular}

${ }^{a} \mathrm{CDCl}_{3}, 400 \mathrm{MHz}$,

${ }^{b} \mathrm{CDCl}_{3}, 600 \mathrm{MHz}$ 
Table 2

${ }^{13} \mathrm{C}$ NMR data $\left(\delta_{\mathrm{C}}\right)$ for compounds $1-4$

\begin{tabular}{|c|c|c|c|c|}
\hline position & $\mathbf{1}^{a}$ & $2,,^{a b}$ & $3,,^{a b}$ & $4^{a}$ \\
\hline 1 & 49.0 & 47.8 & 47.6 & 46.8 \\
\hline 2 & 39.1 & 38.4 & 38.6 & 48.2 \\
\hline 3 & 128.7 & 129.8 & 129.6 & 132.4 \\
\hline 4 & 131.0 & 131.6 & 131.4 & 132.1 \\
\hline 5 & 32.9 & 33.4 & 33.2 & 43.1 \\
\hline 6 & 29.4 & 29.5 & 29.3 & 36.8 \\
\hline 7 & 20.2 & 20.9 & 20.6 & 29.7 \\
\hline 8 & 30.6 & 31.2 & 30.4 & 40.2 \\
\hline 9 & 29.6 & 30.0 & 29.8 & 47.6 \\
\hline 10 & 44.6 & 44.2 & 44.2 & 47.2 \\
\hline 11 & 180.0 & 174.4 & 174.5 & 177.0 \\
\hline 12 & 95.1 & 109.5 & 109.4 & 94.9 \\
\hline 13 & 173.7 & 185.1 & 184.3 & 169.7 \\
\hline 14 & 101.8 & 97.8 & 98.7 & 106.3 \\
\hline 15 & 162.1 & 165.6 & 165.3 & 167.0 \\
\hline 16 & 16.1 & 16.7 & 16.6 & 22.5 \\
\hline 17 & 186.9 & 163.3 & 161.8 & 57.4 \\
\hline 18 & 22.5 & 23.1 & 22.9 & 23.3 \\
\hline 19 & 13.9 & 14.8 & 14.6 & 21.5 \\
\hline $\mathrm{MeO}$ & 57.8 & - - & -- & 59.0 \\
\hline 20 & - - & 53.3 & -- & - - \\
\hline 21 & - - & 62.1 & -- & -- \\
\hline
\end{tabular}

${ }^{a} \mathrm{CDCl}_{3}, 400 \mathrm{MHz}$.

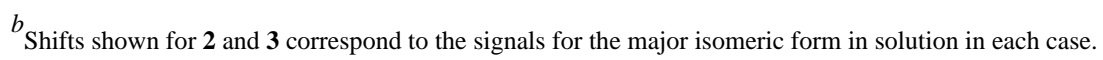


Table 3

${ }^{1} \mathrm{H}$ NMR data $\left[\delta \mathrm{H}\left(\right.\right.$ mult, $\left.\left.J_{\mathrm{H}}\right)\right]$ for compound 2a

\begin{tabular}{cccc}
\hline position & $\mathbf{2}$ & position & $\mathbf{2}$ \\
\hline 2 & $2.79(\mathrm{br} \mathrm{m})$ & $12_{\text {minor }}$ & $5.91(\mathrm{~s})$ \\
3 & $5.29(\mathrm{dt}, 10,2.0)$ & 16 & $0.76(\mathrm{~d}, 7.4)$ \\
4 & $5.57(\mathrm{dt}, 10,3.4)$ & $17_{\text {major }}$ & $8.27(\mathrm{~d}, 13)$ \\
5 & $2.39(\mathrm{br} \mathrm{m})$ & $17_{\text {minor }}$ & $8.42(\mathrm{~d}, 15)$ \\
$6_{\mathrm{eq}}$ & $1.72(\mathrm{~m})$ & 18 & $0.98(\mathrm{~d}, 7.4)$ \\
$6_{\mathrm{ax}}$ & $1.23(\mathrm{~m})$ & 19 & $1.04(\mathrm{~s})$ \\
$7_{\mathrm{eq}}$ & $1.50(\mathrm{~m})$ & $20_{\text {major }}$ & $3.60(\mathrm{q}, 5.3)$ \\
$7_{\mathrm{ax}}$ & $1.50(\mathrm{~m})$ & $20_{\text {minor }}$ & $3.66(\mathrm{q}, 5.3)$ \\
$8_{\text {eq }}$ & $1.34(\mathrm{brd}, 12)$ & 21 & $3.86(\mathrm{br} \mathrm{t}, 5.3)$ \\
$8_{\text {ax }}$ & $1.50(\mathrm{~m})$ & $\mathrm{NH}_{\text {major }}$ & $11.88(\mathrm{br} \mathrm{s})$ \\
9 & $1.51(\mathrm{~m})$ & $\mathrm{NH}_{\text {minor }}$ & $10.16(\mathrm{br} \mathrm{s})$ \\
10 & $2.21(\mathrm{br} \mathrm{d}, 7.2)$ & $\mathrm{OH}_{\text {major }}$ & $2.00(\mathrm{br} \mathrm{s})$ \\
$12_{\text {major }}$ & $5.86(\mathrm{~s})$ & $\mathrm{OH}_{\text {minor }}$ & $2.03(\mathrm{br} \mathrm{s})$ \\
\hline
\end{tabular}

${ }^{a} \mathrm{CDCl}_{3}, 300 \mathrm{MHz} .{ }^{1} \mathrm{H}$ NMR signals for the major and minor forms were not clearly resolved for the modified decalin portion of the molecule or for $\mathrm{H}_{2}$-21, but some of the corresponding signals did appear to be broadened. 